* Corresponding author

Phone +421556022456

E-mail address: maria.kenderova@tuke.sk

(Ing. Mária Kenderová)

Article information

Article history: AMS-Volume16-No.3-00149-12

Received 12 June 2012

Accepted 28 August 2012

\section{Selected Problems and the Interpretation of the Application of Contoured Photoelastic Sheets to Irregularly Shaped Structural Elements}

\author{
František Trebuňa* , Peter Frankovský, Mária Kenderová, Kristína Masláková
}

Department of Applied Mechanics and Mechatronics, Faculty of Mechanical Engineering, Letná 9, 04200 Košice, Slovak Republic

\section{BIOGRAPHICAL NOTES}

Dr.h.c. mult. prof. Ing. František Trebuňa, CSc. is a professor of applied mechanics, Head of the Department of Applied Mechanics and Mechatronics and Dean of the Faculty of Mechanical Engineering. He is author of 10 monographs, 12 university textbook, special book publications, 12 university notebooks and more than 300 publications in journals and conference proceedings at Slovakia abroad. He is author of important projects and engineering works. He received several prizes at home and abroad. He received three titles Doctor Honoris Causa (DHC) including two from foreign universities for the development of applied mechanics and mechatronics.

Ing. Peter Frankovský, PhD. He is a senior assistant on Department of Applied Mechanics and Mechatronics. In 2010 he received PhD. in the field of applied mechanics. He works on scientific and research projects on the department and publishes the results in journals and conference proceedings at Slovakia and abroad. He made remarkable work on the building of laboratories and on publication of monographs and university textbook at the department.

Ing. Mária Kenderová, after successful completion of her study at the SPŠS in Kosice she has started studies at the Faculty of Mechanical Engineering of the Technical university of Kosice. She graduated a bachelor-degree study in General Engineering in 2008. Thereafter she continued an engineer-degree study in Automotive Production. She defended his diploma thesis "Inovative methods of product design - design of automotive component." in 2010. Nowadays she is a student of PhD-degree study in Applied mechanics. Ing.Kristína Masláková, she is a postgraduate student in study field Applied Mechanics and Mechatronics at Technical university in Košice. She has finished her doctoral study in study field Applied mechanics. She worked on scientific and research projects on the department and published the results in conference proceedings and journals. Now she works as a FEA Analyst/Engineer in international company DJH Engineering center, Inc. Her professional activity is oriented into the area of modeling, simulation and calculation of residual stresses and strain fields.

\section{KEY WORDS}

Contoured photoelastic sheet technique, contoured photoelastic sheet PL-1, PhotoStress ${ }^{\circledR}$ method, pressure vessel

\section{ABSTRACT}

Proper selection and application of photoelastic coating to analysed surface of a struc- 
tural element or its part is crucial when analysing principal strains or principal normal stresses by means of PhotoStress ${ }^{\oplus}$ method. For the purpose of this method, the selection of photoelastic coating is as crucial as the selection of a strain gauge and adhesive for tensometric analysis. This paper is hence aimed at this relatively important issue of stress analysis performed through PhotoStress ${ }^{\circledR}$ technique. In this paper, the selection and the application of photoelastic coating are being demonstrated on irregularly shaped surface of one pressure vessel.

\section{Introduction}

PhotoStress ${ }^{\oplus}$ technique is used for measurements of surface strains and stresses in construction parts or systems under static or dynamic loading.

In this method a special strain-optic sensitive photoelastic coating is being applied to analysed surface of a construction part. If the coating is applied to the surface of some loaded construction part and then illuminated with polarized light from reflection polariscope, strain or stress distribution on the coating can be observed through analyzer as colourful isochromatic fringes. The fringes reveal overall distribution of strains and stresses and, at the same time, pinpoint high strain and stress areas. Besides visual information on overall strain and stress distribution, quantitative analysis can be performed using optical compensator bonded to reflection polariscope. With PhotoStress ${ }^{\circledast}$ method simple and quick quantitative strain and stress analysis can be performed.

PhotoStress ${ }^{\circledR}$ method enables us to...

\section{- identify critical areas,}

- highlight high or low stress ranges,

- determine stress concentrations around holes, notches, fillets or other potential failure areas,

- optimize stress distribution in construction parts and systems for minimum weight and maximum reliability,

- measure principal normal stresses and their directions in different points of the applied photoelastic coating,

- repeatedly perform measurement during different loadings without new coating to be applied,

- perform stress measurements in laboratory conditions or in field,

- identify and measure residual stresses.

\section{Pressure Vessel Characteristics}

In this paper, the selection and the application of contoured photoelastic sheet are being demonstrated on the surface of a pressure vessel with the volume of 1 litre (Fig. 1).

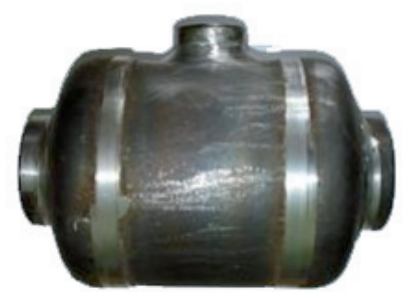

Fig. 1: Pressure vessel.

Its parameters listed in Fig. 2 are needed to estimate the parameters of photoelastic sheet. The pressure vessel was made from non-alloyed finegrained construction steel 11 523. Its Young's modulus equals $\mathrm{E}=2,1.105 \mathrm{MPa}$ and its Poisson's ratio $\mu=0,3$. The mean thickness of the pressure vessel wall is circa $3,8 \mathrm{~mm}$.

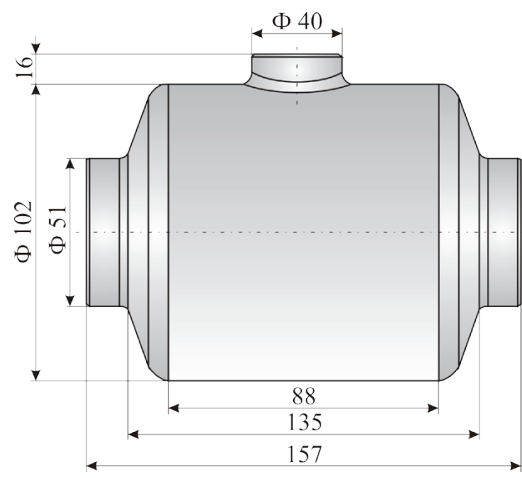

Fig. 2: Parameters of the pressure vessel.

\section{Selection of Photoelastic Coating}

Selecting photoelastic material, it is highly required to follow systematic procedure in order to prevent omitting one or more crucial considerations. The main requirement is to select coating material that will ensure maximum reliability and accuracy of given set of measuring conditions $[2,11]$. As far as the selection of photoelastic coating of the pressure vessel is concerned, the following criteria were taken into account:

a) the method of plastic application to the surface,

b) birefringent sensitivity of the coating, 
c) shape irregularity,

d) reinforcing effect of the pressure vessel,

e) maximum elongation,

f) the impact of temperature during testing.

\section{a) method of plastic application to the surface}

Photoelastic coatings are available in two forms:

\section{- solid flat sheets,}

- iquids for casting contourable sheets.

Solid flat sheets are commonly applied to regularly shaped construction parts. Hence, liquid contourable photoelastic coatings are used for construction parts that cannot be covered with solid flat coating sheets. The pressure vessel photoelastic coating was demonstratively applied to does not have flat surface. For that reason, contourable photoelastic coating must be applied.

\section{b) birefringent sensitivity of the coating}

The sensitivity criterion is one of the most important considerations when selecting coating. Coating sensitivity $f$ is included in the basic equation which is commonly used in principal strain analysis performed through PhotoStress ${ }^{\circledR}$ method:

$\varepsilon_{1}-\varepsilon_{2}=N \cdot f$,

where: $\varepsilon_{1}, \varepsilon_{2}$ stand for strains [-], $N$ represents the fringe order value [-], $f$ represents fringe constant value or birefringent sensitivity of photoelastic coating $[\mu \mathrm{mm} / \mathrm{mm}]$.

The lower the value of fringe constant, the higher the birefringent sensitivity of a photoelastic coating. It is derived from the following relation

$$
f=\frac{\lambda}{2 t_{C} K},
$$

where: $\lambda$ stands for wave length of white light in polariscope $(0,575.10-6 \mathrm{~m}), t_{c}$ thickness of photoelastic coating $(\mathrm{mm}), K$ strain-optic coefficient of photoelastic coating [-].

\section{c) shape irregularity}

This criterion relates to cases when the surface to be covered with contourable photoelastic coating has small-radius curvature. The thickness of the coating needs to be chosen properly, so that the sheet can be contoured over projections and into recesses while maintaining uniform thickness. The thickness of the coating, hence, should be less than 20 per cent of curvature radius of the surface.

\section{d) reinforcing effect of the pressure vessel}

As a common rule of thumb, the reinforcing ef- fect of the photoelastic coating has to be taken into account so as to get possibly the most precise results. The applied photoelastic coating reinforces the pressure vessel and transforms some loading. As a result, measured strain values are lower than in case without coating being applied to the surface. For this reason, correction coefficient $C_{N}$ was derived for long cylindrical vessel which is closed with bottoms and loaded with inner overpressure. In the equation for correction coefficient $C_{N^{\prime}}$ it was in a simplifying way agreed that Poisson's ratio of photoelastic material equals Poisson's ratio for the material of the pressure vessel ( $\left.\mu_{C}=\mu\right)$. Then, correction coefficient for pressure vessels $C_{N}$ will be derived from

$$
C_{N}=\frac{1}{A *-B *}
$$

while

$$
\begin{aligned}
& A *=\frac{2\left(1-2 \mu+\frac{R_{C}}{R}\right)(1-\mu)}{\left[1-2 \mu+\left(\frac{R_{C}}{R}\right)^{2}\right]+\frac{E_{C}}{E} \frac{\left(\frac{R_{C}}{R}\right)^{2}-1}{1-\left(\frac{r}{R}\right)^{2}}\left[1-2 \mu+\left(\frac{r}{R}\right)^{2}\right]}, \\
& B *=\frac{1-2 \mu}{1+\frac{E_{C}}{E} \frac{\left(\frac{R_{C}}{R}\right)^{2}-1}{1-\left(\frac{r}{R}\right)^{2}}},
\end{aligned}
$$

where: $R, r$ represent inner and outer radius of the pressure vessel, $R_{C}$ outer radius of the applied photoelastic coating, $E_{,} E_{C}$ elastic modulus of vessel material and photoelastic coating, $\mu$ Poisson's ratio of the material of the pressure vessel.

Relations of correction coefficients for steel pressure vessels depending upon geometrical features of that particular vessel and photoelastic coating are depicted in Fig. 3.

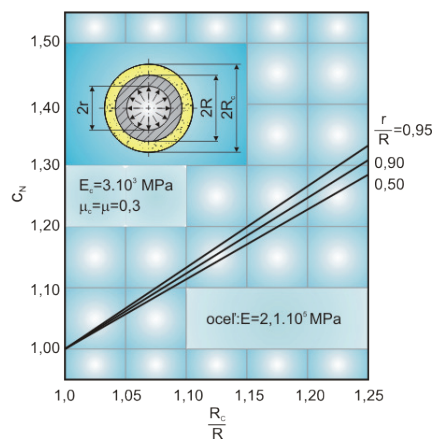

Fig. 3: Correction coefficients for steel pressure vessels. 


\section{e) maximum elongation}

In selection of photoelastc coating, it is necessary to count with its maximum measured strain, which relates to the S-N curve and linearity of photoelastic features. Table 1 lists allowable elongations for selected types of contourable materials of photoelastic coating.

Table 1: Acceptable elongations of liquid coating materials.

\begin{tabular}{|l|l|l|}
\hline Coating material & $\begin{array}{l}\text { Maximum } \\
\text { elongation }\end{array}$ & Application \\
\hline PL-1 & $5 \%$ & $\begin{array}{l}\text { metals, concre- } \\
\text { te, glass, hard } \\
\text { plastics in elastic } \\
\text { or elastoplastic } \\
\text { ranges }\end{array}$ \\
\hline PL-2 & $3 \%$ & $\begin{array}{l}\text { soft materials like } \\
\text { rubber, plastics, } \\
\text { PL-3 }\end{array}$ \\
PL-6 & $50 \%$ & \\
\hline
\end{tabular}

After considering this criterion, photoelastic material PL-1 with maximum elongation 5 per cent was selected.

\section{f) the impact of temperature during testing}

The test of the pressure vessel will be performed at room temperature. The impact of temperature during testing can be ignored. Technical information on given coating material PL-1 normally refers to its properties at room temperature. Fig. 4 illustrates the relation of strain-optic coefficient depending upon temperature. Photoelastic coating PL-1 exhibits two temperature ranges in which the strain-optic coefficient $K$ is stable even if temperature is significantly changing. The pressure vessel will be examined at room temperature without considerable temperature changes, so the value of strain-optic coefficient can be regarded as constant.

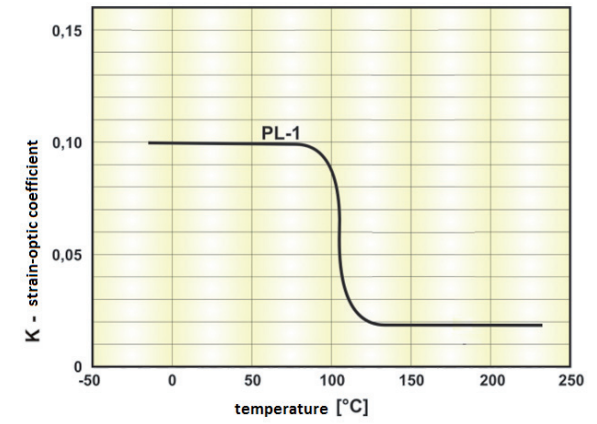

Fig. 4: Dependence of strain-optic coefficient upon temperature.
After considering stated criteria for selection of photoelastic coating, liquid contourable photoelastic coating PL-1 with thickness $0,2 \mathrm{~cm}$ was chosen to be applied to the pressure vessel. Mechanical and optic properties of the coating are stated in publication [10]. Correction coefficient of the selected coating with thickness $0,2 \mathrm{~cm}$ was derived from relation (4) and its value is $C_{N}=1,01028$.

For bonding contoured photoelastic coating to the surface of the pressure vessel the adhesive PC-1 (Fig.5) was used. It exhibits perfect seal toughness and no tendency to slide during application. The adhesive hardens relatively quickly (10 hours) and has low viscosity. These features enable easy handling.

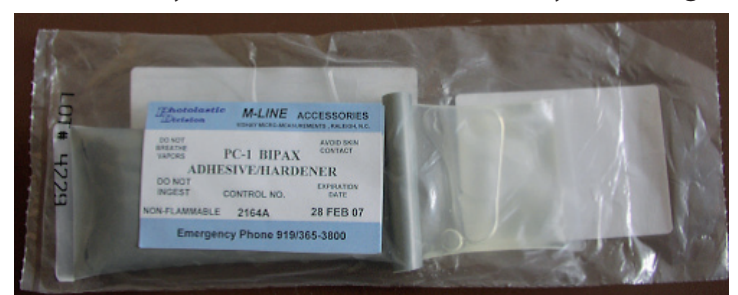

Fig. 5: Two-component adhesive PC-1.

\section{Castinf and Contouring Photoelastic Sheet}

For casting contourable photoelastic sheet were prepared required equipment and Teflon casting plate in the laboratory. The plate was properly cleaned with a gauze sponge soaked with acetone. Then, a thin layer of releasing agent "Photoelastic Releasing Agent" was put on the surface of the casting plate and thin film was applied to it (Fig.6). The film prevents casted coating from sticking to the casting plate and simultaneously ensures its smooth removal. The releasing agent was applied to the film too. To assure uniform thickness of the coating the casting plate had to be horizontally levelled.

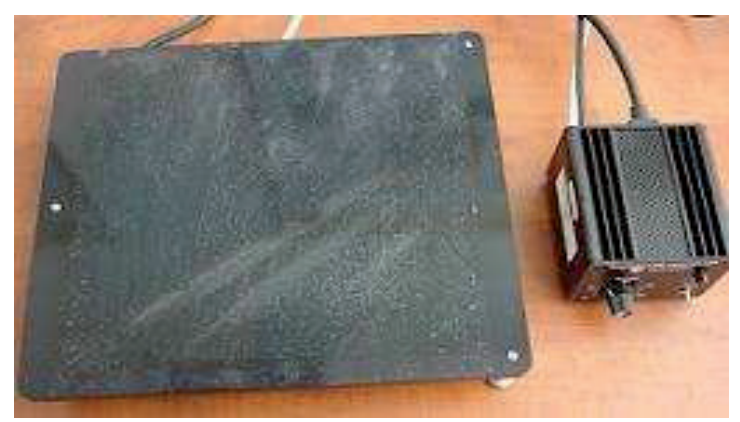

Fig. 6: Casting plate with applied film and releasing agent. 
After the casting plate had been levelled, a casting mould was prepared from properly cleaned silicon snap-together frame that was coated with releasing agent in advance. Final parameters of the mould were $24 \times 22 \mathrm{~cm}$. Casting area is $0,6 \mathrm{~cm}$ longer and wider since it is needed to trim the meniscus that arises during the process of pouring liquid resin. The snap-together frame allows casting coating sheet of any size, even to the size of the plate. After putting the frame together, the casting area was covered with plexiglas plate to be kept away from dust (Fig.7).

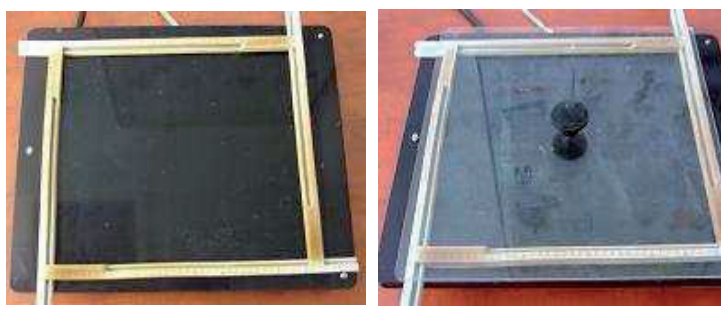

Fig. 7: Snap-together frame and its plexiglas cover.

After the preparation of casting area, the next step was to prepare liquid photoelastic coating, which is a mixture in proper proportion of resin to hardener. The amount of resin and hardener was set from the total weight of the mixture required for coating sheet with proper size.

\section{Total weight of the mixture:}

$W=1,13 \cdot A \cdot t$,

where: $W$ is the total weight of required amount of mixture [g], 1,13 - specific weight of mixture $\left[\mathrm{g} / \mathrm{cm}^{3}\right], A$ - surface of photoelastic sheet $\left[\mathrm{cm}^{2}\right], t$ thickness of photoelastic sheet [cm].

\section{Calculation of resin weight:}

$W_{\mathrm{PL}-1}=W \cdot \frac{100}{120}$

were pre-weighed with electronic scale BS 3000A

$W_{P L H-1}=W \cdot \frac{20}{120}$

\section{Calculation of hardener weight:}

Contourable photoelastic coating applied to the pressure vessel had been cast in two procedures and always to uniform size. The size of the sheet and weights of single mixtures are listed in Table 2. Precise amounts of individual mixture components with accuracy $0,1 \mathrm{~g}$.

Table 2: Parameters of photoelastic sheet and weights of individual mixture components.

\begin{tabular}{|c|c|c|c|c|}
\hline $\begin{array}{c}\text { Parameters of the } \\
\text { sheet [cm] }\end{array}$ & $\begin{array}{c}\text { A } \\
{\left[\mathbf{c m}^{2}\right]}\end{array}$ & $\begin{array}{c}\text { W } \\
\text { [g] }\end{array}$ & $\begin{array}{c}\text { WPL-1 } \\
\text { [g] }\end{array}$ & $\begin{array}{c}\text { WPLH-1 } \\
\text { [g] }\end{array}$ \\
\hline $24 \times 22 \times 0,2$ & 528 & 119,3 & 99,4 & 19,9 \\
\hline
\end{tabular}

Resin and hardener, both components being preweighed in precise proportion to each other, were being mixed in a plastic cup with mixing thermometer while trying to avoid the introduction of air bubbles. Mixing must be slow, constant and performed in the same direction, so as to prevent air bubbles in the mixture. These would make contourable sheet non-homogenous. As the mixture temperature reached $48^{\circ} \mathrm{C}$, which is the required temperature, the mixture was poured onto the prepared casting surface. The mixture was being poured slowly and evenly throughout the surface in order to prevent air bubbles even during this procedure. Even when bubbles occurred, they were burst either with the mixing thermometer or a needle. After the mixture was poured out, plexiglas cover was put onto the frame, so as to keep the coating away from dust. The casting procedure of contourable photoelastic coating is shown in Fig. 8.

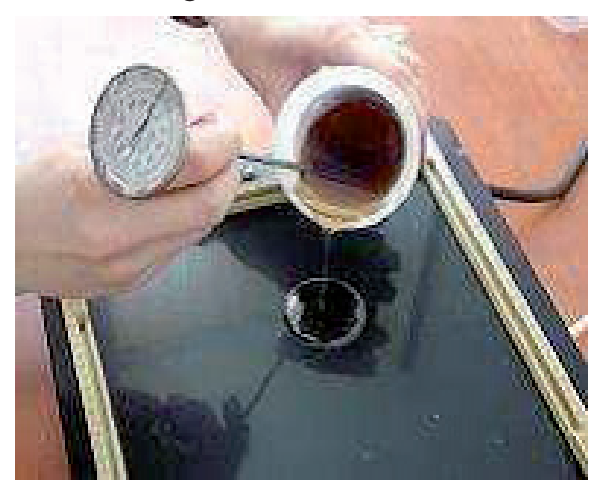

Fig. 8: Pouring contourable photoelastic coating.

After casting, the mixture passed through polymerization reactions and approximately after two hours reached required state. The substance as such was mechanically stable and ready to be removed from the teflon plate (Fig.9) and contoured in order to get required shape of the pressure vessel.

During polymerization cycle of the coating, the surface of the pressure vessel was cleaned with gauze soaked with acetone and coated with min- 
eral oil which prevents the sheet from sticking to the surface of the vessel. After this procedure, the vessel was ready for contouring the photoelastic coating.

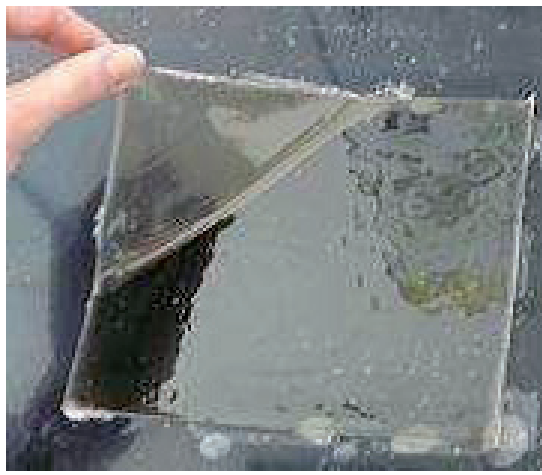

Fig. 9: Removing contourable coating from teflon plate.

Removed and ready-made contourable coating was carefully put onto the application surface of the vessel. Then, it was shaped with short movements of oiled fingertips until it gained the shapes of the pressure vessel surface. The coating must not be pushed, stretched or pressed in a violent way, since its thickness could locally change. The overhangs of the contoured photoelastic sheet were cut off (Fig.10). After contouring, the coating sheet was left on the pressure vessel approximately 18 hours to harden completely.

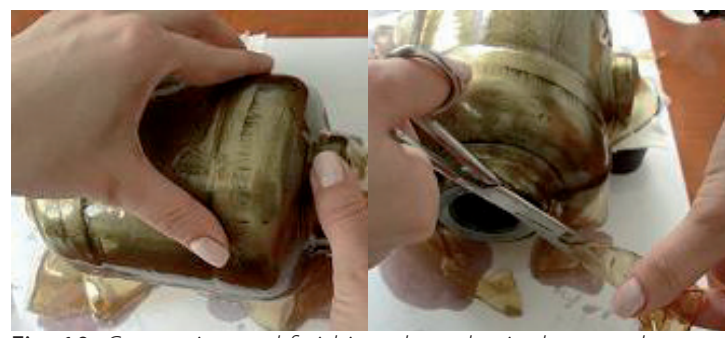

Fig. 10: Contouring and finishing photoelastic sheet on the pressure vessel.

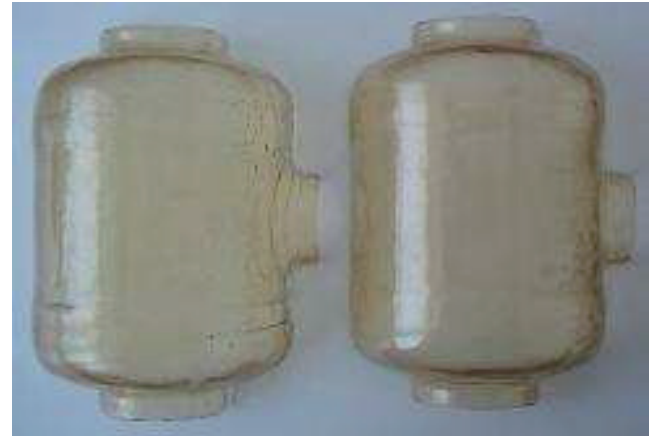

Fig. 11: Removing contourable coating from teflon plate.
After the first part of photoelastic coating had hardened, the other part was casted while following the same procedure as in the first case. Then, after hardening, fine sandpaper was used to sand irregularities of the edges. Fig.11 depicts stiff and worked parts of photoelastic coating of the pressure vessel.

\section{Bonding Photoelastic Sheet Onto the Pressure vessel}

Before bonding, photoelastic sheet was subjected to examination through polariscope. It did not exhibit initial photoelastic effects and could be bonded to the pressure vessel. Bonding must be precise and without errors. The quality of bonding is dependent upon preceding preparation of surface material of tested object, photoelastic sheet, adhesive and bonding procedure. In the first step, the surface of the pressure vessel was precisely cleaned and degreased with acetone and then coated with Photoelastic metal cleaner and worked with fine sandpaper. Then, neutralizing substance was coated with gauze sponge onto the surface of the vessel to ensure optimal $\mathrm{pH}$ factor. After that, both sides of coating parts were precisely cleaned [1].

For bonding contoured photoelastic sheet twocomponent adhesive PC-1 was used. The adhesive was selected with reference to applied photoelastic coating. The amounts of hardener and adhesive were mixed in a proportion that was derived from following relations:

\section{Weight calculation of adhesive PC-1:}

$W_{\mathrm{PC}-1}=W_{\text {celk }} \cdot \frac{100}{110}$

\section{Weight calculation of hardener:}

$W_{P C H-1}=W_{\text {celk }} \cdot \frac{10}{110}$

Relations (8) and (9) refer to two-component adhesive $\mathrm{PC}-1$.

The total amount of adhesive Wcelk was determined according to rough calculation, so that the whole surface of the pressure vessel was covered. The weight of applied adhesive and its components are listed in Table 3.

Table 3: Total weight of adhesive and its components.

\begin{tabular}{|l|l|l|}
\hline Wcelk. $[\mathbf{g}]$ & WPC-1 $[\mathbf{g}]$ & WPCH-1 $[\mathbf{g}]$ \\
\hline 80 & 72,72 & 7,27 \\
\hline
\end{tabular}


In the first step, required amount of adhesive was mixed and applied to the surface of the pressure vessel (Fig.12). Then, one part of the contoured sheet was applied. Initial air bubbles and excessive adhesive were gradually pressed out with appropriate finger pressure. The adhesive was hardening approximately 12 hours. The same application procedure was followed in case of the other part of photoelastic sheet.

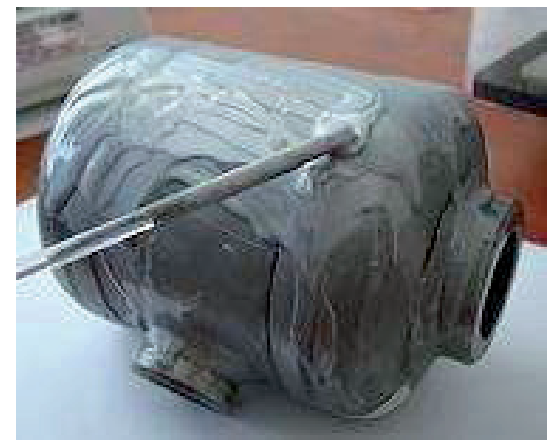

Fig. 12: Coating adhesive onto the surface of the pressure vessel.

As a result, the pressure vessel was coated with contourable photoelastic sheet PL-1 (Fig.13). The vessel is now ready for experimental analysis of principal strains and principal normal stresses using PhotoStress ${ }^{\circledR}$ method.

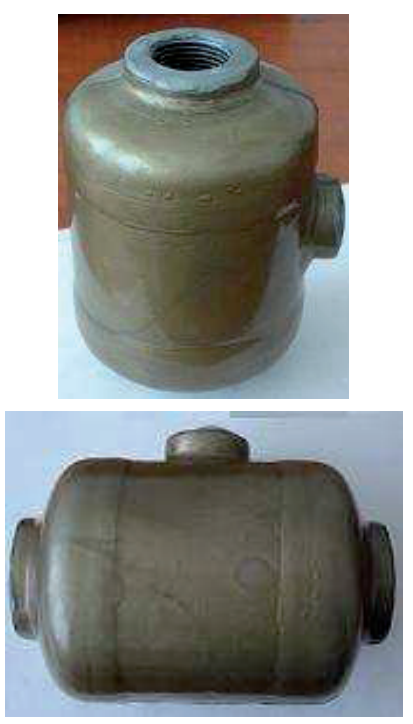

Fig. 13: Pressure vessel with applied photoelastic sheet.

\section{Conclusion}

This contribution demonstrates selection and application of photoelastic coating onto irregularly shaped surface of a 1 litre pressure vessel. Selected and applied was photoelastic sheet PL-1 with thickness of $0,2 \mathrm{~cm}$. For bonding of the photoelastic sheet was used two-component adhesive PC-1. Photoelastic coating PL-1 hardens at ambient temperature, exhibits good birefringent sensitivity and can be used for long-term tests.

Successful fulfilment of selection and application conditions is critical for precise determination of principal strains and principal normal stresses on the surface of analyzed object through PhotoStress ${ }^{\oplus}$ method.

Other measuring procedures for determination of principal normal stresses and principal strains on irregularly shaped objects will be discussed in further contributions.

\section{Acknowledge}

The paper has been created realization of project "Center for research of control of technical, environmental and human risks for permanent development of production and products in mechanical engineering" (IMTS:26220120060), based on operating program support Research and Development financed from European Regional Development Fund and of project APVV-0091-11.

\section{References}

[1] Bulletin IB-223 Instructions for Bonding Flat and Contoured Photoelastic Sheets to Test-Part Surfaces. Measurements Group, Inc., Raleigh, North Carolina, 1996.

[2] Bulletin S-116-H Photoelastic Materials. Measurements Group, Inc., Raleigh, North Carolina, 1996.

[3] Dally J.W., Riley W.F.: Experimental stress analysis, McGrawHill Inc., 2001.

[4] FRANKOVSKÝ, P., KOSTELNÍKOVÁ, A.: Výber fotoelastického povrstvenia a lepidla tlakovej nádoby pre meranie hlavných napätí a deformácií metódou PhotoStress. In: AT\&P Journal plus. č. 1 (2007), s. 102-104. ISSN 1336-5010.

[5] FRANKOVSKÝ, P., MOŠČAK, P.: Meranie a vyhodnotenie hrúbky steny tlakovej nádoby pre potreby metódy PhotoStress. In: Acta Mechanica Slovaca. roč. 12, č. 3-b (2008), s. 209-218. ISSN 1335-2393.

[6] KOBAYASHI, A.S.: Handbook on Experimental Mechanics. Seattle: Society for Experimental Mechanics, 1993, 1020 s. ISBN1-56081-640-6.

[7] Tech Note TN-704 How to Select Photoelastic Coatings. Measurements Group, Inc., Raleigh, North Carolina, 1996.

[8] TREBUŇA, F.: Princípy, postupy, prístroje $v$ metóde PhotoStress. Košice: TypoPress, 2006, 360 s. ISBN 80-8073-670-7. 
[9] TREBUŇA, F. et al.: Akým smerom posúvame súčasné poznatky $\vee$ praktickom uplatnení metódy photostress. In: Experimentální analýza napětí 2007: Sborník 45. mezinárodní konference, Plzeň: Západočeská univerzita, 2007. 10 p. ISBN 978-80-7043-552-6.

[10] TREBUŇA, F. ŠIMČÁK, F.: Príručka experimentálnej mechaniky. Košice:TypoPress, 2007, 1526 s. ISBN 970-80-8073-816-7.

[11] TREBUŇA, F., FRANKOVSKÝ, P., HUŇADY, R.: Optical methods and their application in experimental analysis of mechanical and mechatronic systems. In: Hutnické listy. Vol. 64, no. 7, 2011, p. 173-178. - ISSN 0018-8069.

[12] TREBUŇA, F. et al.: Further Possibilities of Using Software PhotoStress for Separation of Principal Normal Stresses. In: Acta Mechanica Slovaca. Roč. 14, č. 2, 2010, s. 82-91. - ISSN 1335-2393.

[13] TREBUŇA, P.: Plánovanie merania $\vee$ priemyselnom inžinierstve In: Strojárstvo: strojárstvo extra. č. 1-2, 2010, s. 74/8-75/9. ISSN 1335-2938.

[14] ZANDMAN, F., Redner, S. and DALLY, J. W.: Photoelastic Coatings. Ames, lowa: lowa State University Press, 1977.

[15] ZANDMAN, F., WOOD, M.: Photostress Analysis. Prod. Engng. $1956,27,9$.

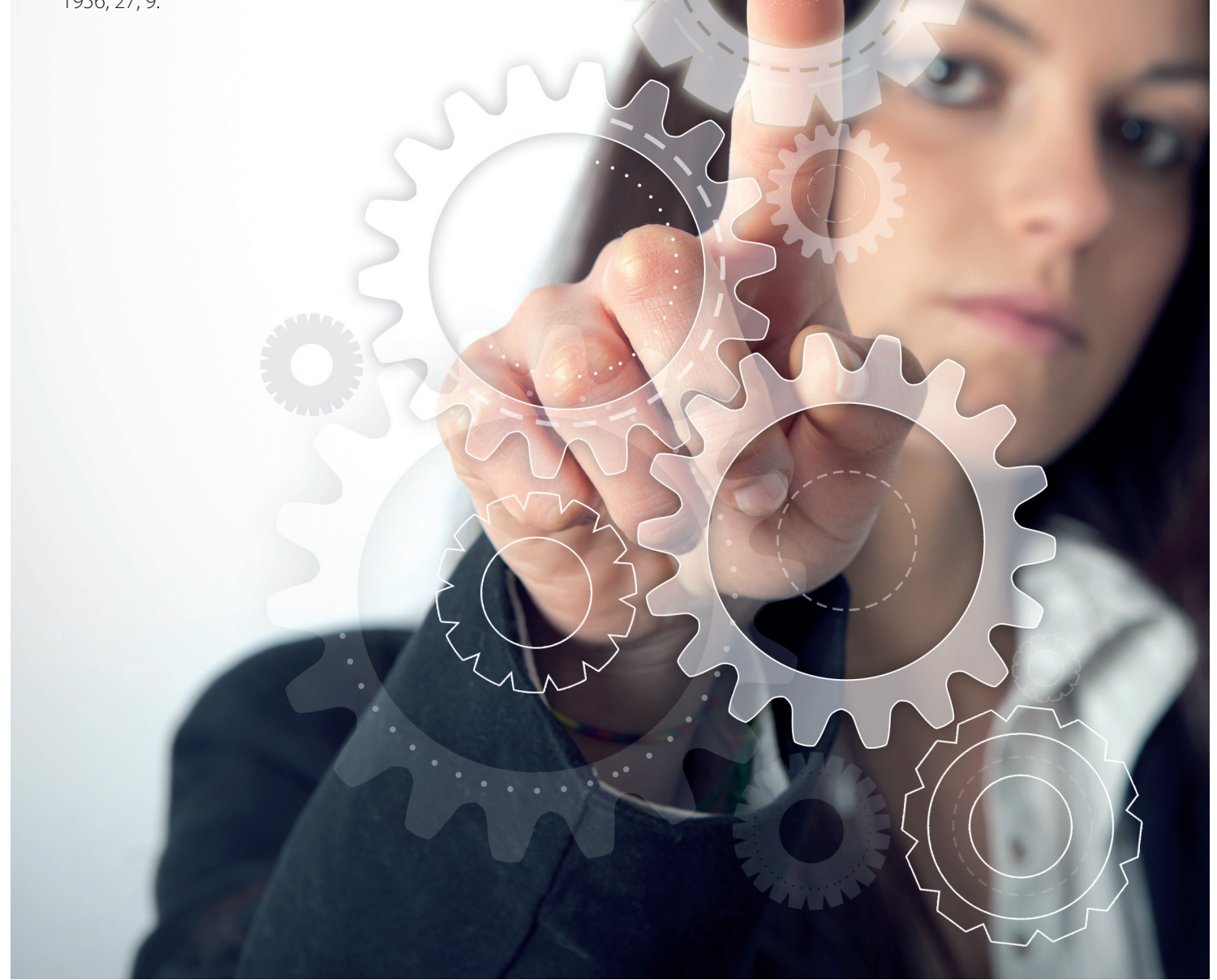

